\title{
Characterization of Climatic Data for Predicting Growing Period, the Case of Maichew, Northern Ethiopia
}

\author{
Molla Mekonnen Alemu \\ United Nations Development Programme, Freetown, Sierra Leone \\ Email: mollamekonnen@gmail.com
}

Received 5 March 2016; accepted 21 March 2016; published 25 March 2016

Copyright (C) 2016 by author and OALib.

This work is licensed under the Creative Commons Attribution International License (CC BY). http://creativecommons.org/licenses/by/4.0/

(c) (i) Open Access

\begin{abstract}
In terms of improved crop production, knowledge and information of the crops and crop varieties grown in a given area is a better measure of climate, as applied to crop production in that region, than are complete climatic records. Water is the main element of living plant tissues. Water facilitates the movement of nutrients from the soil to the plant roots and upward throughout the plant tissues. It also provides hydrogen as an element of organic materials formed during photosynthesis. The transpiration of water also helps to cool plants during harsh temperature conditions. The effectiveness of a given rainfall for crop production highly depends on the time of the year that it falls along with its intensity. In moisture deficit areas, the deficiency could be overcome by supplementary irrigation and moisture conserving agronomic practices. Apart from this, the use of improved varieties like early maturing crops will also hold a paramount importance to combat such problems. In arid and semi-arid zones, the conservation and efficient utilization of the available scanty rainfall plays a significant role in the whole production system since it can relegate all other factors, including soil fertility, to minor positions. Therefore, knowledge on growing period has a central role in improving crop production. Thus, this paper is aimed at characterizing climatic data for predicting the growing period in the case of Maichew, Northern Ethiopia.
\end{abstract}

Keywords

Climatic Data, Growing Period, Rainfed

Subject Areas: Ecosystem Science

\section{Introduction}

Climate is among the prime factors that determine the suitability of a specific crop for a given area. Climate

How to cite this paper: Alemu, M.M. (2016) Characterization of Climatic Data for Predicting Growing Period, the Case of Maichew, Northern Ethiopia. Open Access Library Journal, 3: e2560. http://dx.doi.org/10.4236/oalib.1102560 
constitutes a complex set of inter-related elements whereby a slight change in one variable could easily trigger smooth changes in most other elements. This change will in turn affect agricultural activities which are the source of all food items consumed by humans and domesticated animals [1].

Agricultural activities are totally dependent on weather and climate that will have a serious implication on the food security efforts which is currently strained by the ever increasing human population and increased demand and the growth of natural resources use [2].

According to Fajer and Bazzaz (1992), "agriculture faces a particularly difficult dilemma: should it begin adapting at high cost to uncertain climatic changes while seeking the resolution of the scientific issues concerning the magnitude of climate change and its impact on agriculture, or choose the 'business-as-usual' principle and run the risk of leaving future generations unprepared when changes materialize? Although clear-cut answers might not be available for at least the next decade, improving scientific knowledge on the agronomic and ecological effects of any climate change, both adverse and positive, and on the ability of humans and ecosystems to adapt, might reduce the uncertainty and help formulate better policy”. Thus, whichever policy and strategy are formulated and adopted it should always be assessed periodically and remain flexible to accommodate new developments with the changing climate complex [1] [3].

The current scientific knowledge has provided a worthy understanding on plant physiology, growth and development. For instance, information on the response of plants to different temperature ranges, rainfall, moisture, sunshine, humidity, etc. is well documented. However, a higher degree of risk and uncertainty clouds the potential negative effects of climate change on different agro-ecologies mainly due to shortage and lack of appropriate climatic data, low level of knowledge on sustainable utilization of resources, insufficient institutional capacity and other related factors. Therefore, increasing the resilience of agricultural production by lessening production risks associated with weather and climatic variability will help to boost up food security opportunities as well as the strengthening of livelihoods development.

Relating agricultural activities towards seasonal climatic prediction can help to boost production systems since it will help to use resources like precipitation in an efficient and productive way. It will also help to coup up and adapt to climate change effects [4] [5]. Therefore, this article is aimed at characterizing climatic data for predicting the growing period and biomass production in the case of Maichew, Northern Ethiopia.

\section{Objective}

The main objective of this paper is by making use of climatic data, characterize the growing period and estimate the potentials of the Maichew area of northern Ethiopia for wheat crop production.

\section{Methodology}

For the compilation of this paper, climate data for two decades (1994-2015) was collected from the National Meteorological Agency of Ethiopia. The last two decades most recent data was considered as it reflects the recent climatic pattern of the area. Different books, scientific journals and lecture notes were reviewed to explore climate and its related impact on food security and agricultural productions. Apart from these, researcher's field level observations were also used as an input for the compilation of the article.

Ann and Eric (2014) defined growing period as the continuous period during the year when rainfall exceeds half the reference evapotranspiration, calculated by Penman's method, plus a period required to evapotranspire up to $100 \mathrm{~mm}$ of water from excess precipitation assumed stored in the soil profile at the end of the rains. They also mentioned as growing period can be determined graphically or can also be computed using the linear or parabolic interpolation techniques and reference is made from this for the analysis of the climatic data.

\section{Results and Discussion}

\subsection{Description of the Study Site}

Maichew is one of the district towns located in the Southern Zone of Tigray Regional State of Ethiopia. It is situated at $12^{\circ} 46^{\prime} \mathrm{N}$ latitude and the altitude ranges from 1200 - 2478 meters above sea level. It is located at about 665 kilometers north of Addis Ababa, the capital of Ethiopia. According to Ethiopia's agro-ecological setting, Maichew and its surrounding environments are classified under the "Weinadega" (semi-temperate zone). Subsistence agriculture is the major source of livelihood in the area with an average 0.75 hectares of cultivated land. Teff, barley, wheat, horse bean, sorghum, finger millet and chickpea are the major crops of the area [6]. 


\subsection{Crop Growth and Development}

Crop growth is "the quantitative, irreversible increases in weight or size of plant cells, organs, or the entire plant and development as the qualitative changes in function or number of cells, tissues, organs, or the entire plant" [7]. Different climatic factors like precipitation, temperature, etc. along with other physical and biological factors will determine the growth and development of crops in various ways (Table 1). For instance, each crop has its own approximate temperature range, i.e., its minimum, optimum, and maximum ranges for its growth and development. Crops also differ in the number of heat units that are required to mature them. The effect of temperature on photosynthesis depends on the type of plant species, the environmental conditions under which the plant is growing. Plants also need different amount of water for transpiration and evaporation across the different growth stages of the plant.

\subsection{Growing Wheat}

Wheat is believed to evolve from wild grasses and is assumed to have first been cultivated in between 15,000 and 10,000 BC. It is one of the largest grain crops in the world. Wheat belongs to the genus Triticum that includes the common bread wheat (Triticum aestivum) and durum (Triticum turgidum). The growth and development phases of wheat are complex processes whereby lots of its growth stages will overlap on each other. When one part of the crop may be developing another part of the crop might be dying [9].

Wheat can be grown both in rainfed and irrigation areas. It grows in temperate, tropics and sub-tropical climatological zones with an altitude of more than $1500 \mathrm{~m}$. The total growing period of wheat can range from 100 150 days based on the type of varieties, climatic and other factors like soil type. It can also grow by the minimum daily temperatures of about $5^{\circ} \mathrm{C}$. The mean daily temperature for optimum growth and tillering is however between $15^{\circ} \mathrm{C}-20^{\circ} \mathrm{C}$ and maximum temperature is 350 . The annual rainfall requirement of the crop is from 750 to $1600 \mathrm{~mm} /$ year [8] [10] [11].

Wheat can grow on different types of soils ranging from desert soils to clay soils but, medium textures are preferred. The optimum soil $\mathrm{pH}$ ranges from 6 to 8 . For productive and better yields the fertilizer rates could be up to $150 \mathrm{~kg} / \mathrm{ha} \mathrm{N,} 35$ - $45 \mathrm{~kg} / \mathrm{ha} P$ and 25 - $50 \mathrm{~kg} / \mathrm{ha} \mathrm{K} \mathrm{[10]} \mathrm{[11].}$

\subsection{Determination of Growing Period}

The growing period in Maichew district begins from mid-June and ends during the last week of October which is about 120 days in total. The area also receives significant amount of rainfall during the months of March, April and May (Table 2 and Figure 1). The precipitation which will be received during this period can easily be utilized for land preparation like tilling, for early preparation of seed bed and other farm management activities

Table 1. Effect of major climatic factors on crop water needs [8].

\begin{tabular}{|c|c|c|}
\hline \multirow{2}{*}{ Climatic Factor } & \multicolumn{2}{|c|}{ Crop water need } \\
\hline & High & Low \\
\hline Sunshine & sunny (no clouds) & cloudy (no sun) \\
\hline Temperature & hot & cool \\
\hline Humidity & low (dry) & high (humid) \\
\hline Wind speed & windy & little wind \\
\hline
\end{tabular}

Table 2. Rainfall and ETo data of Maichew.

\begin{tabular}{|c|c|c|c|c|c|c|c|c|c|c|c|c|}
\hline Climatic Variables & Jan & Feb & Mar & Apr & May & Jun & Jul & Aug & Sep & Oct & Nov & Dec \\
\hline Rain fall (mm) & 21 & 12 & 45 & 70 & 61 & 29 & 183 & 234 & 76 & 56 & 30 & 23 \\
\hline $\begin{array}{c}\text { Evapotranspiration } \\
1(\mathrm{~mm})\end{array}$ & 42 & 43 & 53 & 58 & 62 & 53 & 43 & 38 & 40 & 48 & 47 & 43 \\
\hline $\begin{array}{c}\text { Evapotranspiration } \\
2(\mathrm{~mm})\end{array}$ & 42 & 45 & 58 & 59 & 62 & 47 & 40 & 37 & 42 & 52 & 45 & 42 \\
\hline
\end{tabular}




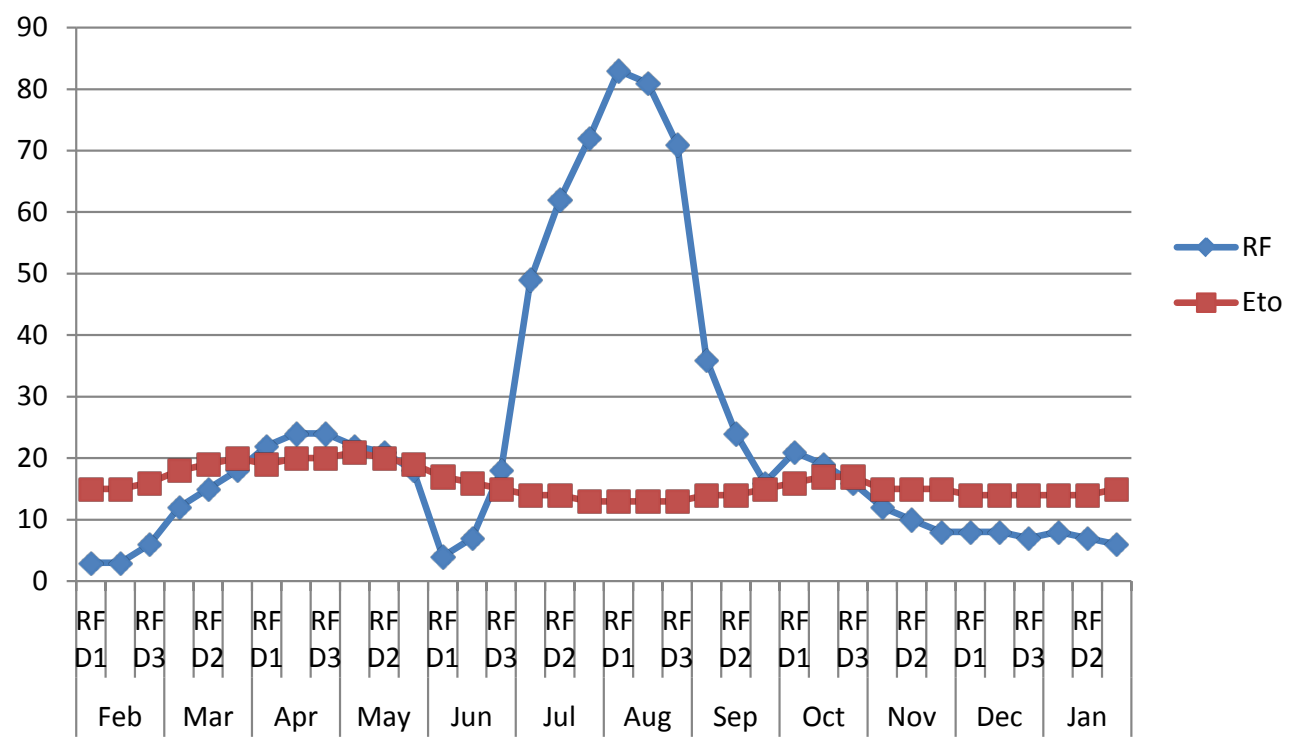

Figure 1. Graphical representation of growing period (GP) based on the decade data.

so that the farm can be ready timely to make use of the actual growing period which starts in June. However, it must be noted that, other factors like soil type, crop varieties, and market demand sides of the production needs to be further investigated in order to have a complete picture of the production cycle.

From Figure 1, it is possible to have a look as there is a significant amount of rainfall (from March to May) other than the main rainy season, indicating as there is a strong potential of using this rainfall for early preparation of seed bed and as well planting crops like chickpea, vetch, etc. which doesn't require high amount of water for their growth.

The Linear equation was also used to determine the beginning and end of the growing period making use of the below equation [12] and same result was obtained from the computation.

$$
t=\frac{\text { int eger }[(R 1-\text { ETo1 } / 2) 30]}{(R 1-R 2+\text { ETo2 }- \text { ETo1 })}
$$

The prefix integer is used to leave the fraction without rounding.

Conditions:

-if R1 < ETo2 and R2 > ETo 2, then we use the equation to calculate the beginning of GP.

-if R1 > ETo2 and R2 < ETo2, then we use the equation to calculate the end of rains.

\section{Conclusion}

The research result showed that Maichew has a prolonged growing period which fit in to the growth and development of different crops like wheat. The two decades climatic information of Maichew was matched with wheat crop production specific climatic requirements and it is possible to confirm that the Maichew area is suitable for the growth and development of wheat. However, the suitability of other factors like soil type and its related factors needs to be further experimented. The area is also receiving a significant amount of rainfall before the actual growing season therefore, if appropriate sustainable land management practices such as early preparation of seedbeds, land clearing, residue management, etc. activities are performed timely the area can have a great potential to increase crop production and productivity.

\section{References}

[1] Sombroek, W.G. and Bazzaz, F.A. (1996) Global Climatic Change and Agricultural Production: An Assessment of Current Knowledge and Critical Gaps. FAO, Rome.

[2] Rosenzweig, C. and Parry, M.L. (1994) Potential Impact of Climate Change on Food Supply. Nature, 367, 133-138. http://dx.doi.org/10.1038/367133a0 
[3] Fajer, E.D. and Bazzaz, F.A. (1992) Is Carbon Dioxide A “Good” Greenhouse Gas? Effects of Increasing Carbon Dioxide on Ecological Systems. Global Environmental Change: Human and Policy Dimensions, 2, 301-310. http://dx.doi.org/10.1016/0959-3780(92)90047-B

[4] McKeon, G.M., Howden, S.M., Abel, N.O.J. and King, J.M. (1993) Climate Change: Adapting Tropical and Subtropical Grasslands. Proceedings of the XVII International Grassland Congress, New Zealand, 8-21 February 1993, 11811190.

[5] Nicholls, N. and Wong, K.K. (1990) Dependence of Rainfall Variability on Mean Rainfall, Latitude and the Southern Oscillation. Journal of Climatology, 3, 163-170. http://dx.doi.org/10.1175/1520-0442(1990)003<0163:DORVOM>2.0.CO;2

[6] Kahsay, S. and Mulugeta, M. (2014) Determinants of Rural Household Food Insecurity in Laelay Maichew Woreda Tigray, Ethiopia. African Journal of Agriculture and Food Security, 2, 106-112.

[7] Chastain, T.G. (2015) Crop Growth and Development. CROP 200 Crop Ecology and Morphology. Oregon State University. http://horticulture.oregonstate.edu/system/files/u528/Crop\%20Growth\%20and\%20Development.pdf

[8] FAO (1986) Irrigation Water Management: Irrigation Water Needs. Via delle Terme di Caracalla, Rome.

[9] NSW (State of New South Wales) (2007) Wheat Growth and Development. Department of Primary Industries, Sydney.

[10] FAO (2015) Crop Water Information: Wheat. http://www.fao.org/nr/water/cropinfo_wheat.html

[11] AIB (My Agri Information Bank) (2015) Ecological Requirement for Wheat Cultivation. http://www.agriinfo.in/default.aspx?page=topic\&superid=1\&topicid=1173

[12] Verdoodt, A. and Vanranst, E. (2014) Land Evaluation. Part III: Quantitative Methods. International Centre for Physical Land Resources, Belgium. 